\title{
FACTOR ANALYSIS EVALUATION OF SCHEIN'S CAREER ORIENTATIONS INVENTORY IN COLOMBIA
}

\author{
Julián David CORTÉS-SÁNCHEZ ${ }^{1}$, Merlin Patricia GRUESO-HINESTROZA²
}

\author{
Universidad del Rosario - School of Management, Entrepreneurship and Innovation Campus, \\ Autopista norte \# 200, Bogotá, Colombia \\ E-mails: julian.cortess@urosario.edu.co (corresponding author $)^{1}$; merlin.grueso@ urosario.edu.co ${ }^{2}$
}

Received 09 May 2017; accepted 14 July 2017

\begin{abstract}
The Career Orientation Inventory model proposed by Edgar Schein is one of the most discussed methods for identifying individuals' career orientations. However, there are several gaps related to its implementation for developing countries using factor analysis and digital open access data. We conducted exploratory and confirmatory factor analysis for a sample of 116 employees of a contact center in Colombia to test whether there were significant differences among career anchors (CAs) and gender, educational attainment, or age. The results show: a different number of factors from those proposed by Schein; variances in security/stability and managerial competence CAs concerning gender and educational attainment; and lifestyle is not the dominating $\mathrm{CA}$ in women.
\end{abstract}

Keywords: career orientation inventory; career anchors; psychometric evaluation; human resources management.

JEL Classification: J24; O15; M12; M54.

\section{Introduction}

Current and incoming employees' career paths and orientations should be identified as a strategic task in order strengthens job commitment. The Career Orientation Inventory (COI) model proposed by Edgar Schein is one of the most cited and discussed methods intended to identified individuals' career paths and orientations (Rodrigues et al. 2013). The model has been widely used and refined in diverse contexts and locations (e.g. COI model implementation in human talent acquisition processes (see Donohue and Power 2014, Dumitrescu 2009); health practitioners (see Kaplan et al. 2009); the tourism sector (see Beck and La-Lopa 2001, La-Lopa et al. 2009); or expatriates and migrants (see Cerdin and Le-Pargneux 2010). More than 20 years after Schein's seminal studies, Feldman and Bolino (1996) mentioned that the model has made several contributions, such as it can predict individuals' career path choices, among other remarkable findings. Despite of this, the model also has been widely criticized, providing empirical evidence on the existence of individuals' multiple career paths (Chapman and Brown 2014), mutually exclusive and complementary career paths (Feldman and Bolino 1996, Chapman and Brown 2014) and incompleteness in terms of inclusion of values and motivational domains (Wils et al. 2010,2014). Furthermore, COI literature has lacked of empirical studies using exploratory and confirmatory factor analysis in developing countries and detailed open access data for replicability and further meta-studies (Barclay et al. 2013, Open Science Collaboration 2015).

To address these gaps, in this study, we aim to discuss the results of exploratory and confirmatory factor analysis of the COI based on a sample of 116 employees of a contact center located in Bogotá, Colombia. By achieving this, we conducted the first Schein COI study in Colombia to provide new insights into this model in developing countries; we provided an open access data-driven study; and we addressed the methodological gap indicated by Leong et al. (2014) that is related to the fewer studies in which exploratory and confirmatory factor analysis were conducted. After this introduction, we present a literature review. Later, we conduct an exploratory and confirmatory factor analysis. Then, we discuss the results. Finally, we present the conclusions and limitations of the study.

\section{Literature review}

COI literature is divided into three branches: seminal, mainstream, and critical. The seminal branch consists of the original studies conducted by Schein in the 1970s. The objectives of these studies were twofold: to understand the impact of personal values and career events, and analyze how individuals make career specialty choices based on their career anchors (CAs) on the Massachusetts Institute of Technology (MIT) Sloan School of Management graduates' professional lives (Schein 1974, 1975). Personal values and career events also can be seen as internal 
and external career orientations (Brent et al. 2013; Igbaria et al. 1991). Internal career orientations define careers as individual perceptions about work or how to create meaning from interactions with others (Blustein and Nourmair 1996, Derr and Laurent 1989). Conversely, external career orientations understand careers objectively as organizational opportunities and limitations selected or discarded by employees according to their experiences and qualifications (Babalola and Bruning 2015). To reach a consensus between internal and external career orientations, the concept of CA emerged. The CA of an individual can be defined as self-perceived talents, abilities, and values, and the sense of motives and needs that govern one's work and personal-related choices, which evolve as one gains work and life experience (Schein 1974, 1975, 1978, 1987, 1990). In his first study, Schein (1974) identified five CAs: (1) managerial competence; (2) technical/functional competence; (3) organizational security; (4) entrepreneurial creativity; and (5) autonomy. In subsequent studies, Schein $(1987,1990)$ identified three more CAs: (6) service/dedication to a cause; (7) pure challenge; and (8) lifestyle (See Appendix for an extended description of each CA). Two decades after Schein's first study, Feldman and Bolino (1996) concluded that there were five remarkable theoretical contributions: (1) individuals' career identities develop through work and life experience, are not defined at a young age; (2) individuals choose career paths within occupations rather than just occupations (e.g., the managerial competence track in advertising rather than "management" or a pure challenge track in a nongovernmental organization rather than "supply-chain"); (3) individuals' career paths in the same vocation might change as much as they would if they were in different industries; (4) individuals' career paths with the same CA might be similar across industries; and (5) CAs can predict career choices.

The mainstream branch consists of studies conducted to refine the COI model and address the sample limitations of the seminal studies. To ensure a close relationship with participants, Schein (1974) decided the following: (1) not to include foreign students, students who were going to be drafted, students who wanted to enter the military, and potential PhD students; and (2) to interview a small sample of 44 graduate students of MIT Sloan School of Management, applying qualitative methodologies (i.e., semi-structured interviews). These two methodology considerations were viewed as flaws by later career theory scholars because of the relatively small size of the sample, its homogeneity (Feldman and Bolino 1996), and the unidimensional methodological approach (Nordvik 1996). Consequently, numerous researchers have reproduced the COI using larger, heterogenic samples for diverse geographical contexts, industries, and subjects regarding the following: (1) career and job satisfaction (Danziger and Valency 2006, Guan et al. 2014); (2) career trajectories, decisions, and mobility (Chapman and Brown 2014, Gubler et al. 2015, McDonald et al. 2005, Miranda et al. 2011, Tremblay et al. 2014); (3) human talent acquisition (Donohue, Power 2014, Dumitrescu 2009); (4) retention and turnover decisions (Chang et al. 2011, 2012); (5) health practitioners (Kaplan et al. 2009); (6) the tourism sector (Beck and La-Lopa 2001, La-Lopa et al. 2009); (7) undergraduate students' career orientation (D'Silva and Hamid 2014, Luo and Zhang 2011); (8) expatriates and migrants (Cerdin and Le-Pargneux 2010); and (9) the effects of sexual identity and preferences on career experiences and decisions (Kaplan 2014). Among these studies, Danziger et al. (2008: 17) claimed to have published the first rigorous construct measurement model of Schein's COI by means of confirmatory factor analysis applied to a sample of 1,847 Israeli working adults who completed the COI questionnaire. Danziger et al. (2008) supported the validity of Schein's CA theory; although, they confirmed a distinction between entrepreneurship and creativity, which were considered to be two separate CAs, as Marshall and Bonner predicted in 2003 (Marshall and Bonner 2003). Consequently, the COI should have nine CAs instead of eight. Moreover, Danziger et al. stated that these findings were not population specific and could be generalized to Western societies (Danziger et al. 2008: 17). Similarly, by means of confirmatory factor analysis applied to a sample of 238 working adults in Greece, Mihail (2008) drew a similar conclusion to Danziger et al. (2008): despite the emergence of a "new" career orientation, namely "boundaryless" (Arthur 1994) or "protean" (Hall and Mirvis 1995), the primary source for shaping a career's path was the individual's CA. Nevertheless, these two Western society-focused studies were not unambiguous. Mihail (2008) argued than personal and work characteristics, such as gender, age, and work experience do not have an effect on a respondent's career path. By contrast, Danziger and Valency (2006), by means of cross tabulation and a chi-square significance test applied to the same sample they used in 2008, concluded that the percentage of women with lifestyle as their dominant CA was almost twice that of men. In fact, significant differences between women and men's CAs were found, with two exceptions: technical/functional competence and security. The se results do not provide evidence of the generalizations of Danziger's et al. (2008) results in so-called Western societies. Similar discussions were addressed in studies conducted in developing countries. In the Nigerian context, Ituma and Simpson (2007), by means of a grounded theory $(n=30)$ and factor analysis approach $(n=336)$, maintained the following: (1) a high unemployment rate and wage variation led to a new career emergence: being marketable; (2) in addition to being marketable, security was the dominant CA; (3) there was no evidence of the existence of a service/dedication to a cause CA; and (4) COI confirmatory analyses work better in terms of five out of six CAs identified (i.e., being stable, being balanced, being challenged, being free, and being in charge). In the Iranian context, Alavi et al. (2012) presented evidence that supported the existence of the "being marketable" value, which belongs to the technical/functional competence. Additionally, another CA was identified: project oriented. These 
results highlighted the significance of in-context studies for understanding differences across neglected regions in COI literature, such as Nigeria, Iran and, in the case of this study, Colombia.

The critical branch consists of studies conducted to discuss the current validity of the original COI proposal considering present-day unforeseen work dynamics (Rodrigues et al. 2013). Feldman and Bolino (1996) proposed an alternative conceptualization of Schein's CA typology through three contributions. First, they proposed three dimensions of CAs that determine their impact on success and effectiveness: (1) CAs focused on the type of work individuals do day in, day out, or talent-based (i.e., managerial competence, technical/functional competence, and entrepreneurial creativity); (2) CAs grounded in individuals' needs and motives, or needs-based (i.e., organizational security, autonomy, and lifestyle); and (3) CAs grounded in a person's attitudes and values, or value-based (i.e., service/dedication to a cause and pure challenge). Second, they argued that is possible for an individual to have multiple CAs - which Schein $(1974,1990)$ argued in his seminal studies as an exception - for at least three reasons: (1) Schein's COI includes CAs that do not only address career events (e.g., an individual could have both technical/functional and organizational security despite the former belonging to the talent-based dimension and the latter to the needs-based dimension); (2) individuals could experience ambivalence caused by two or more equally attractive objectives; or (3) no one career path seems any more desirable than any other. Third, based on the study conducted by Nordvik (1996), Feldman and Bolino (1996) proposed that some CAs attract each other, such as organizational security, service/dedication to a cause, and lifestyle; and some CAs exclude each other, such as entrepreneurial creativity and security, or pure challenge and lifestyle (Figure 1).

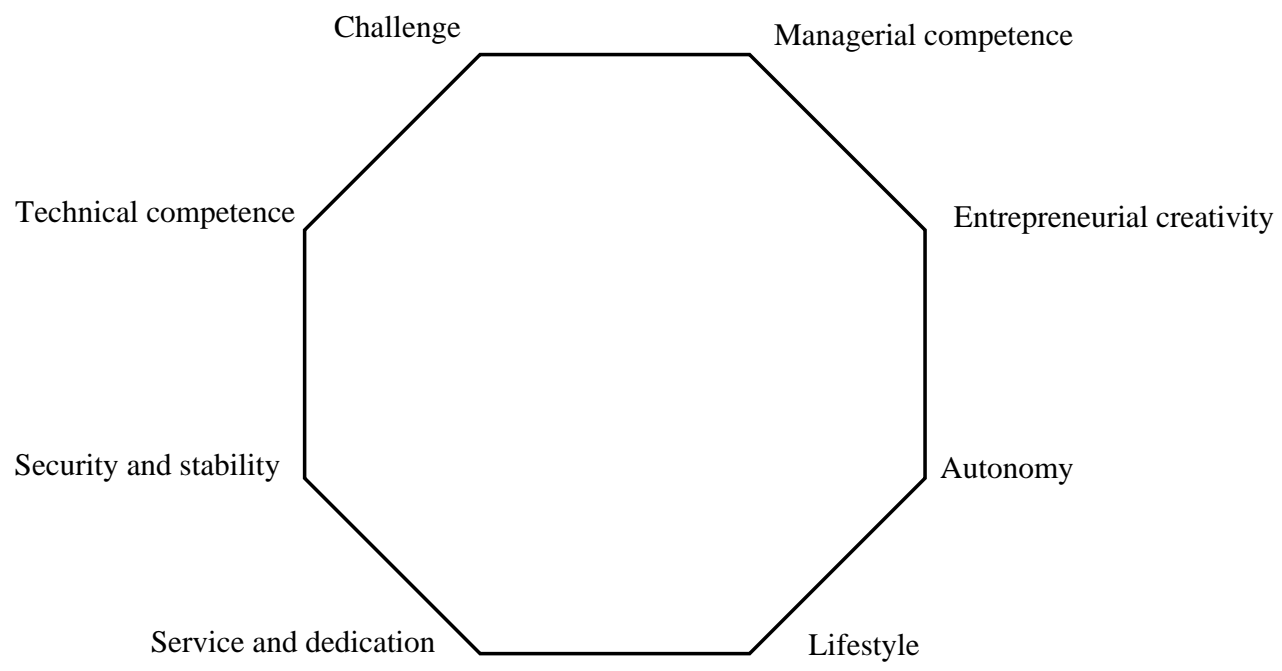

Fig. 1. Factor structure underlying career anchors (source: Feldman, Bolino 1996: 106)

Considering these future research proposals, Chapman and Brown (2014) provided empirical support to Feldman and Bolino (1996) statements. By means of indices of mutual presence applied to a sample of 1,361 multinational company employees, they concluded that $40 \%$ of the participants had multiple CAs and only $12.9 \%$ had only one. Feldman and Bolino (1996) predictions were also supported: lifestyle, organizational security, and service/dedication to a cause were complementary CAs, whereas entrepreneurial creativity and security were exclusive. However, the octagonal complementary/exclusion model proposed by Feldman and Bolino (1996) proved to be too limiting because some CAs' relationships were misrepresented and others were not represented at all (Barclay et al. 2013, Chapman and Brown 2014, Roger 2006). To address this theoretical gap, Wils et al. (2010, 2014), by means of Guttman-Lingoes smallest space analysis applied to a sample of 880 engineers, proposed an original model for the COI based on Schwartz's universal values structure (UVS) (Schwartz and Boehnke 2004) called the career value structure (CVS). The UVS is a circular model intersected by two axes distributed to four quadrants and divided into 10 motivational domains. The horizontal axis opposes "openness to change" and "conservation." The vertical axis opposes "self-transcendence" and "self-enhancement." The 10 motivational domains are universalism and benevolence (i.e., self-transcendence quadrant); tradition, conformity, and security (i.e., conservation quadrant); power and achievement (i.e., self-enhancement quadrant); hedonism, stimulation, and self-direction (i.e., openness to change quadrant). Following this approach, the CVS is a circular model based on the correspondence between the four quadrants, 10 aforementioned motivational domains, and Schein's CAs, as follows: technical/functional competence and service/dedication to a cause are located in the self-transcendence 
quadrant; lifestyle and organizational security are located in the conservation quadrant; managerial competence and identity are located in the self-enhancement quadrant; and pure challenge, entrepreneurial creativity, and autonomy are located in the openness to change quadrant. Wils et al. (2010, 2014) concluded that several CAs are complementary (e.g., creativity and challenge), whereas others are conflictual (e.g., challenge and security). Conversely, the axis's correlation analysis indicates that each quadrant is negatively correlated with the others. As a result, CVS flexibility allows for rigorous and consistent CA data analysis with a b roader conceptual framework, such as the UVS to represent accurately the interaction between CAs and motivational domains (Figure 2).

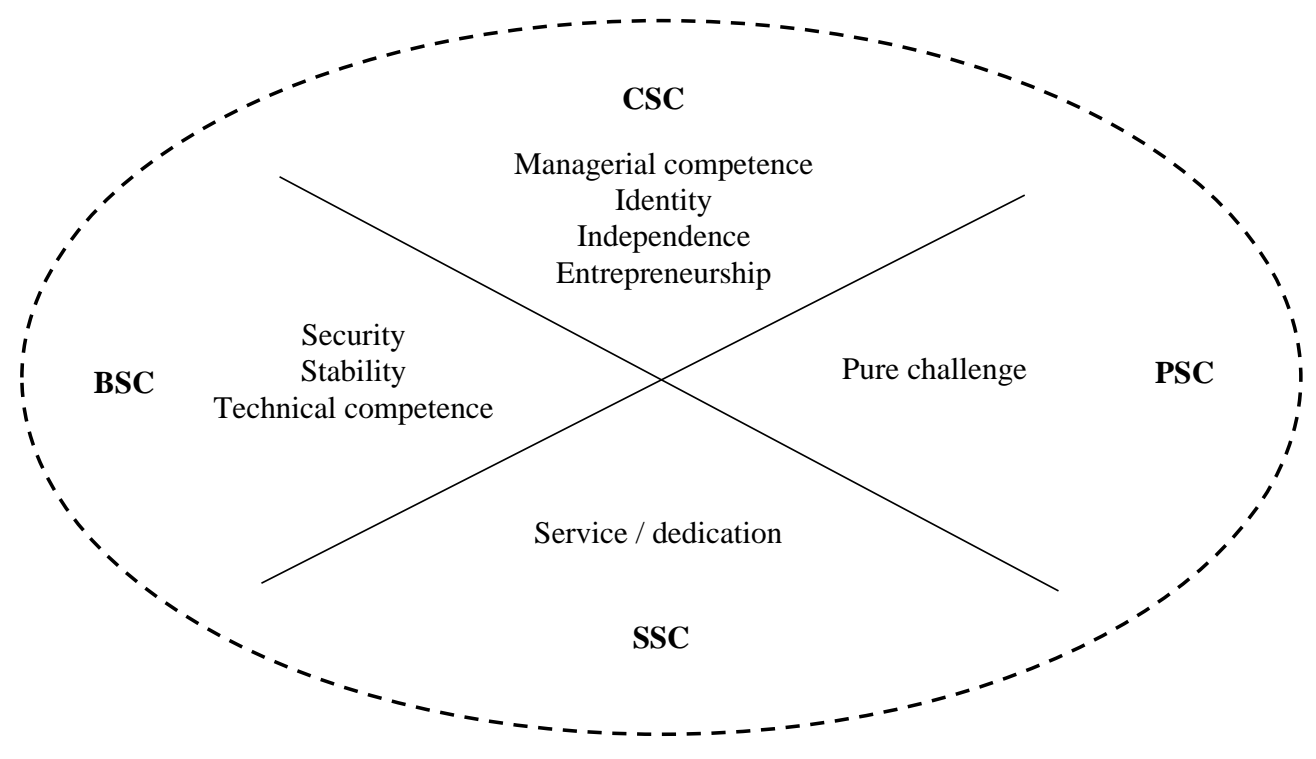

Fig. 2. Career anchors and value career structure quadrants (source: Wils et al. 2014: 828)

Note: careerist self-concept (CSC); protean self-concept (PSC); social self-concept (SSC); and bureaucratic self-concept (BSC).

Considering these findings, this study has the following aims: to conduct the first Schein COI study in Colombia to provide new insights into this model in developing countries; to provide an open access data-driven study, and hence, address the evidence gap identified by Barclay et al. (2013), for which they found that only seven out of 90 studies contained the detailed information required (e.g. correlation matrix between the CAs); and to address the methodological gap indicated by Leong et al. (2014) that is related to the fewer studies in which exploratory and confirmatory factor analysis were conducted.

\section{Methodology}

\subsection{Sample and questionnaire}

This study was conducted in a contact center located in Bogotá, Colombia. The data were collected using an online survey from August to November 2015 with the approval of the senior management committee and the IT department. The questionnaire that was used and translated into Spanish was the same as was used by Danziger et al. (2008) (Appendix). The questionnaire assessed eight CAs: (1) functional/technical competence; (2) managerial competence; (3) autonomy/independence; (4) security/stability; (5) entrepreneurship/creativity; (6) service/dedication; (7) pure challenge; and (8) lifestyle. A 1 to 4 Likert scale was used $(1=$ totally disagree; $4=$ totally agree). The authors and the senior management committee, both considered valuable to understand the career orientation of the call center agents, due two reasons: (1) higher withdrawal rate; and (2) heterogeneity in terms of educational attainment and previous work experience. A random sample of call center agents was considered. A total of 116 call center agents agreed to participate voluntarily in the study. All 116 call center agents fulfilled the questionnaires. Table 1 presents the gender, age, and educational attainment for the sample. ${ }^{1}$

Table 1. Gender, age, and educational attainment for the sample

\footnotetext{
${ }^{1}$ The survey data are available online in Spanish. Permanent link: https://goo.gl/Cm2QaY .
} 


\begin{tabular}{|c|c|}
\hline \multicolumn{2}{|l|}{ Sample size } \\
\hline $\mathrm{n}$ & 116 \\
\hline \multicolumn{2}{|l|}{ Gender } \\
\hline Men & $70.7 \%$ \\
\hline Women & $29.3 \%$ \\
\hline \multicolumn{2}{|l|}{ Age } \\
\hline $18-25$ & $69 \%$ \\
\hline $26-35$ & $16.4 \%$ \\
\hline $36-45$ & $4.3 \%$ \\
\hline $45-55$ & $2.6 \%$ \\
\hline N/A & $7.8 \%$ \\
\hline \multicolumn{2}{|l|}{ Educational attainment } \\
\hline ISCED* level 2 y 3 : lower and upper secondary & $38.8 \%$ \\
\hline $\begin{array}{l}\text { ISCED level 4: post-secondary non-tertiary } \\
\text { education }\end{array}$ & $37.1 \%$ \\
\hline ISCED level 5: short-cycle tertiary education & $12.1 \%$ \\
\hline ISCED level 6: bachelor's or equivalent & $12.1 \%$ \\
\hline
\end{tabular}

*Note: International Standard Classification of Education (source: authors).

\subsection{Rotated component matrix}

The 39-item questionnaire yielded .69 on the Kaiser-Meyer-Olkin measure of sampling adequacy (MSA). An MSA above .60 justifies conducting factor analysis and suggests adequate common variance among the items (Kaiser 1970). Using principal axis factoring extraction, we identified 12 factors with eigenvalues above one that explained $67 \%$ of the variance. We analyzed items weights for each factor in the rotated component matrix. We analyzed the correlation matrix to observe the association between items and their statistical significance. We found that functional/technical competence and lifestyle items loaded in six out of the 12 factors. We observed that items related to functional/technical competence and lifestyle had a low statistical association between them, with no statistical significance in most cases. Therefore, we decided to eliminate the functional/technical and lifestyle CAs from the analysis. For the remaining CAs, the degree of association between items and their level of significance was analyzed.

Thus, we performed a new factor analysis for six factors. We also calculated Cronbach's reliabilities to evaluate the internal reliability of each anchor. The 18 items yielded .674 on Kaiser-Meyer-Olkin measure of MSA. Using principal axis factoring extraction, we identified six factors with eigenvalues above one. These six factors accounted for $69 \%$ of the variance. As shown by our results in Table 2, items mc2, mc3, and mc4 loaded into the managerial competence (MAC) factor, with weights ranging from 0.61 to 0.86 . Items auto1, auto2, and auto3 loaded into the autonomy (AUT) factor, with weights ranging from 0.572 to 0,872 . Items sec 3 , sec 4 , and sec5 loaded into the security (SEC) factor, with weights ranging from 0.80 to 0.83 . The entrepreneurship (ENT) factor weights were between 0.79 and 0.87 . Items serv1, serv2, and serv4 loaded into the service (SER) factor, with weights ranging from 0.53 to 0.82 . Finally, items chal2, chal4, and chal5 loaded into the challenge (CHA) factor, with loadings ranging from 0.70 to 0.84 .

Table 2. Rotated component matrix

\begin{tabular}{|c|c|c|c|c|c|c|}
\hline & \multicolumn{6}{|c|}{ Components } \\
\hline & SEC & ENT & CHAL & SER & AUT & MAC \\
\hline $\operatorname{mac} 2$ & & & & & & .618 \\
\hline
\end{tabular}




\begin{tabular}{l|l|l|l|l|l|l} 
mac3 & & & & & & .861 \\
\hline mac4 & & & & & & .711 \\
\hline aut1 & & & & & .713 & \\
\hline aut2 & & & & & .872 & \\
\hline aut3 & & & & & .572 & \\
\hline sec3 & .822 & & & & & \\
\hline sec4 & .805 & & & & & \\
\hline sec5 & .830 & & & & & \\
\hline ent1 & & .799 & & & & \\
\hline ent2 & & .821 & & & & \\
\hline ent3 & & .879 & & & & \\
\hline ser1 & & & & .821 & & \\
\hline ser2 & & & & .747 & & \\
\hline ser4 & & & & .538 & & \\
\hline cha2 & & & .702 & & & \\
\hline cha4 & & & .840 & & & \\
\hline cha5 & & & .802 & & & \\
\hline
\end{tabular}

Note: Principal axis factoring with varimax rotation. Factors had eigenvalues of above 1.00. Items sorted by size of loadings (source: authors).

\subsection{Reliability assessment}

We assessed the reliability of the items' internal consistency in relation to the construct. A way to calculate this is using a composite reliability coefficient. According to Hair et al. (2014), a composite reliability coefficient should be 0.70 or higher. Using Cronbach scores, the composite reliability was within the limits defined by Hair et al. (2014): managerial competence (0.78), autonomy/independence (0.77), security/stability (0.86), entrepreneurship/creativity (0.87), pure challenge (0.83), and service/dedication (0.75).

\subsection{CA differences between means by gender}

We tested whether there were significant differences in CAs by gender by calculating the differences between means. There were significant differences in security/stability between males and females. There were no significant differences in the other CAs (Table 3).

Table 3. ANOVA: CAs by gender

\begin{tabular}{l|l|r|r|r|r|r}
\hline \multicolumn{2}{c|}{} & Sum of squares & DF & Mean squares & F & Sig. \\
\hline \multirow{4}{*}{ MAC * gender } & Between groups & .430 & 1 & .430 & 1.719 & .192 \\
\cline { 2 - 8 } & Within groups & 28.496 & 114 & .250 & & \\
\cline { 2 - 8 } & Total & 28.926 & 115 & & & \\
\hline \multirow{3}{*}{ AUT * gender } & Between groups & .014 & 1 & .014 & .054 & .817 \\
\cline { 2 - 8 } & Within groups & 29.223 & 114 & .256 & & \\
\cline { 2 - 8 } & Total & 29.237 & 115 & & & \\
\hline \multirow{3}{*}{ ENT * gender } & Between groups & 1.419 & 1 & 1.419 & 7.321 & .008 \\
\cline { 2 - 8 } & Within groups & 22.100 & 114 & .194 & & \\
\cline { 2 - 8 } & Total & 23.519 & 115 & & & \\
\hline \multirow{3}{*}{ SER * gender } & Between groups & .003 & 1 & .003 & .012 & .913 \\
\cline { 2 - 8 } & Within groups & 30.919 & 114 & .271 & & \\
\cline { 2 - 8 } & Total & 30.922 & 115 & & & \\
\cline { 2 - 8 } & Between groups & .253 & 1 & .253 & 1.191 & .277 \\
\cline { 2 - 8 } & Within groups & 24.212 & 114 & .212 & & \\
\cline { 2 - 7 } & Total & 24.464 & 115 & & & \\
\hline
\end{tabular}




\begin{tabular}{l|l|r|r|r|r|r}
\multirow{3}{*}{ CHA* gender } & Between groups & .529 & 1 & .529 & 1.764 & .187 \\
\cline { 2 - 7 } & Within groups & 34.186 & 114 & .300 & & \\
\cline { 2 - 7 } & Total & 34.714 & 115 & & & \\
\hline
\end{tabular}

(source: authors)

An analysis of the CAs by gender results show that women scored higher than men in security/stability (Table 4).

Table 4. Differences between means by gender

(source: authors)

\begin{tabular}{l|l|c|c|c|c|c|c}
\hline \multicolumn{2}{l|}{ Gender } & MAC & AUT & SEC & ENT & SER & CHA \\
\hline \multirow{2}{*}{ Male } & Mean & 25.118 & 27.118 & 30.588 & 33.176 & 33.294 & 33.118 \\
\cline { 2 - 8 } Female & SD & .48789 & .41543 & .41313 & .45956 & .38418 & .40659 \\
\cline { 2 - 8 } & Mean & 23.780 & 26.878 & 33.018 & 33.293 & 32.268 & 31.634 \\
\cline { 2 - 8 } Total & SD & .50480 & .53895 & .45089 & .54376 & .48865 & .59556 \\
\cline { 2 - 8 } & Mean & 24.172 & 26.948 & 32.306 & 33.259 & 32.569 & 32.069 \\
\cline { 2 - 8 } & SD & .50152 & .50422 & .45223 & .51855 & .46123 & .54942 \\
\hline
\end{tabular}

\subsection{CA differences between means by educational attainment}

We analyzed whether there were significant differences among CAs based on educational attainment. The results show that there were significant differences in managerial competence (Table 5).

Table 5. ANOVA: CAs by educational attainment

\begin{tabular}{|c|c|c|c|c|c|c|}
\hline & & Sum of squares & DF & Mean squares & $\mathrm{F}$ & Sig. \\
\hline \multirow{3}{*}{ MAC * academic level } & Between groups & 2.789 & 3 & .930 & 3.983 & .010 \\
\hline & Within groups & 26.137 & 112 & .233 & & \\
\hline & Total & 28.926 & 115 & & & \\
\hline \multirow{3}{*}{ AUT $*$ academic level } & Between groups & .187 & 3 & .062 & .240 & .868 \\
\hline & Within groups & 29.050 & 112 & .259 & & \\
\hline & Total & 29.237 & 115 & & & \\
\hline \multirow{3}{*}{ SEC $*$ academic level } & Between groups & .928 & 3 & .309 & 1.534 & .210 \\
\hline & Within groups & 22.590 & 112 & .202 & & \\
\hline & Total & 23.519 & 115 & & & \\
\hline \multirow{3}{*}{ ENT $*$ academic level } & Between groups & .233 & 3 & .078 & .284 & .837 \\
\hline & Within groups & 30.689 & 112 & .274 & & \\
\hline & Total & 30.922 & 115 & & & \\
\hline \multirow{3}{*}{ SER $*$ academic level } & Between groups & .287 & 3 & .096 & .443 & .723 \\
\hline & Within groups & 24.177 & 112 & .216 & & \\
\hline & Total & 24.464 & 115 & & & \\
\hline \multirow{3}{*}{ CHA* academic level } & Between groups & .247 & 3 & .082 & .267 & .849 \\
\hline & Within groups & 34.468 & 112 & .308 & & \\
\hline & Total & 34.714 & 115 & & & \\
\hline
\end{tabular}

(source: authors)

The results for analyzing CAs by educational attainment show that people with a higher attainment degree scored higher than other academic levels (Table 6).

Table 6. Differences between means by educational attainment

\begin{tabular}{l|l|c|c|c|c|c|c}
\hline \multicolumn{2}{l|}{ Academic Level } & MAC & AUT & SEC & ENT & SER & CHA \\
\hline $\begin{array}{l}\text { ISCED level 2 y 3: lower and upper } \\
\text { secondary }\end{array}$ & Mean & 24.933 & 27.067 & 33.000 & 33.600 & 31.956 & 31.689 \\
\cline { 2 - 8 } & SD & .49836 & .57303 & .45415 & .48166 & .41667 & .59384 \\
\hline $\begin{array}{l}\text { ISCED level 4: post-secondary non- } \\
\text { tertiary education }\end{array}$ & Mean & 22.558 & 26.698 & 31.919 & 32.977 & 33.023 & 32.000 \\
\cline { 2 - 8 } & SD & .49824 & .46982 & .44933 & .47081 & .47684 & .47006 \\
\hline $\begin{array}{l}\text { ISCED level 5: short-cycle tertiary } \\
\text { education }\end{array}$ & Mean & 27.286 & 27.857 & 33.214 & 33.857 & 32.714 & 32.429 \\
\hline & SD & .45477 & .39586 & .42095 & .60492 & .48107 & .52141 \\
\hline ISCED level 6: bachelor's or equivalent & Mean & 23.571 & 26.429 & 30.357 & 32.429 & 33.000 & 33.143 \\
\hline
\end{tabular}




\begin{tabular}{l|l|l|l|l|l|l|l} 
& SD & .40137 & .50340 & .45844 & .70243 & .55331 & .68709 \\
\hline \multirow{2}{*}{ Total } & Mean & 24.172 & 26.948 & 32.306 & 33.259 & 32.569 & 32.069 \\
\cline { 2 - 8 } & SD & .50152 & .50422 & .45223 & .51855 & .46123 & .54942 \\
\hline
\end{tabular}

(source: authors)

\subsection{CA differences between means by age}

Finally, we analyzed whether there were significant differences in CAs based on age (Tables 7-8). The results show that there are no significant differences.

Table 7. ANOVA: CAs by age

\begin{tabular}{|c|c|c|c|c|c|c|}
\hline & & Sum of squares & DF & Mean squares & $\mathrm{F}$ & Sig. \\
\hline \multirow{3}{*}{ MAC* age groups } & Between groups & 1.019 & 3 & .340 & 1.277 & .286 \\
\hline & Within groups & 27.407 & 103 & .266 & & \\
\hline & Total & 28.426 & 106 & & & \\
\hline \multirow{3}{*}{ AUT* age groups } & Between groups & 1.672 & 3 & .557 & 2.305 & .081 \\
\hline & Within groups & 24.910 & 103 & .242 & & \\
\hline & Total & 26.582 & 106 & & & \\
\hline \multirow{3}{*}{ SEC $*$ age groups } & Between groups & .122 & 3 & .041 & .187 & .905 \\
\hline & Within groups & 22.341 & 103 & .217 & & \\
\hline & Total & 22.463 & 106 & & & \\
\hline \multirow{3}{*}{ ENT * age groups } & Between groups & .658 & 3 & .219 & .822 & .485 \\
\hline & Within groups & 27.484 & 103 & .267 & & \\
\hline & Total & 28.142 & 106 & & & \\
\hline \multirow{3}{*}{ SER $*$ age groups } & Between groups & .075 & 3 & .025 & .114 & .952 \\
\hline & Within groups & 22.714 & 103 & .221 & & \\
\hline & Total & 22.789 & 106 & & & \\
\hline \multirow{3}{*}{ CHA * age groups } & Between groups & .398 & 3 & .133 & .407 & .748 \\
\hline & Within groups & 33.532 & 103 & .326 & & \\
\hline & Total & 33.930 & 106 & & & \\
\hline
\end{tabular}

(source: authors)

Table 8. Differences between means by age

(source: authors)

\begin{tabular}{l|l|c|c|c|c|c|c}
\hline \multicolumn{1}{l}{ Age groups } & MAC & AUT & SEC & ENT & SER & CHA \\
\hline \multirow{2}{*}{$18-25$ years } & Mean & 24.200 & 27.375 & 32.219 & 33.475 & 32.650 & 32.450 \\
\cline { 2 - 9 } & SD & .51862 & .46833 & .47065 & .52843 & .50091 & .57012 \\
\hline \multirow{2}{*}{$6-35$ years } & Mean & 25.368 & 26.632 & 32.500 & 32.105 & 33.263 & 31.474 \\
\cline { 2 - 8 } & SD & .46213 & .63614 & .46398 & .50979 & .36031 & .56898 \\
\hline \multirow{2}{*}{$46-45$ years } & Mean & 23.200 & 24.400 & 32.000 & 34.000 & 33.200 & 30.000 \\
\cline { 2 - 8 } & SD & .50200 & .26077 & .48088 & .37417 & .36332 & .56569 \\
\hline \multirow{2}{*}{ Total } & Mean & 19.333 & 20.667 & 34.167 & 36.667 & 33.333 & 32.667 \\
\cline { 2 - 8 } & SD & .80829 & .11547 & .14434 & .30551 & .11547 & .61101 \\
\hline & Mean & 24.224 & 26.916 & 32.313 & 33.346 & 32.804 & 32.168 \\
\cline { 2 - 8 } & SD & .51785 & .50078 & .46034 & .51526 & .46367 & .56577 \\
\hline
\end{tabular}

\section{Results analysis}

The results show that the factorial structure that best fits the data was six factors. Functional/technical and lifestyle CAs were excluded. Although this factorial structure was different from Schein's (1975), other studies support this divergence. For instance, Igbaria et al. (1991) identified a COI of 11 factors, Ituma and Simpson (2007) five factors, and Marshall 
and Bonner (2003) and Danziger et al. (2008) of nine factors. As mentioned, Ituma's and Simpson (2007) study is one of the very first conducted on developing countries. They argued that the meanings attached to career and its trajectories will be context dependent; thus socio-cultural and economic conditions should be considered. In the Colombian context, the turnover rate was estimated in $37 \%$ for employees without tertiary education (75.9\% of the sample) (López 2009). Furthermore, in the call center where this study was conducted the turnover rate before three months is $10 \%-12 \%, 2 \%-$ $6 \%$ above the global average in share services industries (Deloitte 2015). This local labor market conditions seems not to encourage strengthening functional/technical or lifestyle CA's, where being marketable could be a new and relevant CA identified on developing countries (Duque et al. 2017).

Mihail (2008) argued that personal and work characteristics have no effect on career orientation. Additionally, Danziger and Valency (2006) claimed that lifestyle was the dominant CA in women. Our results do not maintain consistency of these findings for the overall model. There are significant differences in security/stability and managerial competence CAs regarding gender and educational attainment, and women scored higher than men in security/stability CA. A socioeconomic factor associated with this could be the struggle of women in the Colombian labor market. The unemployment rate of women in Colombia is above the Latin-America average (International Labour Organization [ILO] 2016) and they are $47 \%$ more likely to be unemployed due to productive configurations in cities and educational attainment required to pursuit a professional job (Duque et al. 2017) which put under pressure women to have a preference for security/stability CA.

\section{Conclusions}

Identifying the employees CA's of any given organization, has the potential effect of increasing job commitment as one of the most powerful intangible assets for increasing performance and productivity. The COI proposed by Schein is one of the most cited and discussed methods intended to identify individuals' career orientations. Through a quantitative appraisal, the COI applied in the Colombian context demonstrated several differences compared with those previously established in the literature regarding the following: (1) the number of factors (i.e., six CAs compared with the eight originally proposed by Schein); (2) variances in security/stability and managerial competence CAs concerning gender and educational attainment; and (3) lifestyle is not the dominating CA in women. This study presents two main limitations: (1) although previous literature supports the sample size, it is always desirable to study a wide range and heterogeneous sample in terms of geographic location, culture, socio-economic status, education attainment, and economic sector (public, private and NGO); and (2) the results are based on questionnaires fulfilled once, they are not based on longitudinal evidence. Further research should consider: (1) wide sample heterogeneity, not only among industries but also geographical and socio-economic contexts; (2) estimate the direct effect/impact of the labor market on the individuals CA's; (3) use of quantitative methods to increase their limited existence; (4) longitudinal studies including subjects tracking and monitoring; and (5) data available as digital open access resources to contribute to replicability and transparency.

\section{Acknowledgements}

The authors are thankful for the unconditional support received from Álvaro Márquez and Felipe Santrich.

\section{Funding}

This study was not funded.

\section{Contribution}

The authors contributed equally.

\section{Disclosure statements}

The authors do not have any conflict of interest. 


\section{References}

Alavi S, Moteabbed S, Arasti M (2012) A qualitative investigation of career orientations of a sample of Iranian software engineers. Scientia Iranica 19 (3): 662-673. https://doi.org/10.1016/j.scient.2011.08.033

Arthur M (1994) The boundaryless career: a new perspective for organizational inquiry. Journal of Organizational Behavior 15 (4): $295-306$. https://doi.org/10.1002/job.4030150402

Babalola O, Bruning N (2015) Examining the relationship between individual perceptions of control and contemporary career orientation. Personnel Review 44 (3): 346-363. https://doi.org/10.1108/PR-09-2013-0167

Barclay W, Chapman J, Brown B (2013) Underlying factor structure of Schein's career anchor model. Journal of Career Assessment 21 (3): 430-451. https://doi.org/10.1177/1069072712475179

Beck J, La-Lopa J (2001) An exploratory application of Schein's career anchor inventory to hotel executive operating committee members. International Journal of Hospitality Management 20 (1): 15-28. https://doi.org/10.1016/S0278-4319(00)00035-9

Blustein D, Nourmair D (1996) Self and identity in career development: implications for theory and practice. Journal of Counseling and Development 74 (5): 433-441. https://doi.org/10.1002/j.1556-6676.1996.tb01889.x

Brent W, Chapman J, Brown B (2013) Underlying factor structure of Schein's career anchor model. Journal of Career Assessment 21 (3): 430451.

Cerdin J, Le-Pargneux M (2010) Career anchors: a comparison between organization-assigned and self-initiated expatriates. Thunderbird International Business Review 52 (4): 287-299. https://doi.org/10.1002/tie.20350

Chang C, Chen V, Klein G, Jiang J (2011) Information system personnel career anchor changes leading to career changes. European Journal of Information Systems 20 (1): 103-117. https://doi.org/10.1057/ejis.2010.54

Chang C, Jiang J, Klein G, Chen H (2012) Career anchors and disturbances in job turnover decisions - a case study of IT professionals in Taiwan. Information and Management 20 (1): 309-319. https://doi.org/10.1016/j.im.2012.08.002

Chapman J, Brown B (2014) An empirical study of the career anchors that govern career decisions. Personnel Review 43 (5): $717-740$. https://doi.org/10.1108/PR-01-2013-0017

Danziger N, Rachman D, Valency R (2008) The construct validity of Schein's career anchors orientation inventory. Career Development International 13 (1): 7-19. https://doi.org/10.1108/13620430810849506

Danziger N, Valency R (2006) Career anchors: distribution and impacts on job satisfaction, the Israel case. Career Development International 11 (4): 293-303. https://doi.org/10.1108/13620430610672513

Deloitte (2015) 2015 global shared services survey: survey results https://goo.gl/9e1EwD

Derr B, Laurent A (1989) The internal and external career: a theoretical and cross-cultural perspective, Chapter 22. In: Arthur M, Hall D, Lawrence B (Eds) Handbook of Career Theory. Cambridge: Cambridge University Press. https://doi.org/10.1017/CBO9780511625459.025

Donohue P, Power N (2014) Linking career anchors and social cognitive frameworks: developing an interview instrument. In: SIGSIM-CPR '14 Proceedings of the 52nd ACM conference on Computers and people research, Singapore, Singapore, 29-31 May 2014. https://doi.org/10.1145/2599990.2600010

D'Silva J, Hamid J (2014) Influence of career anchors, work values and personality traits toward employability orientation among Malaysian university students. International Educational Studies 7 (9): 15-23. https://doi.org/10.5539/ies.v7n9p15

Dumitrescu D (2009) Human resources profile in the virtual organization based on the career anchors of Edgar Schein. DAAAM International, Vienna.

Duque J, García G, Herrera P, López E (2017) Heterogeneidad regional en las diferencias por género de las tasas de desempleo, Chapter 4. In: Arango L, Castellani F, Lora E. Desempleo femenino en Colombia. Bogota, Banco de la Republica.

Feldman D, Bolino M (1996) Career within careers: reconceptualizing the nature of career anchors and their consequences. Human Resource Management Review 6 (2): 89-112. https://doi.org/10.1016/S1053-4822(96)90014-5

Guan Y, Wen Y, Xiaohua S, Liu H, Si W, Liu Y, Wang Y, Fu R, Zhang Y, Dong Z (2014) When do salary and job level predict career satisfaction and turnover intention among Chinese managers? The role of perceived organizational career management and career anchor. European Journal of Work and Organizational Psychology 23 (4): 596-607. https://doi.org/10.1080/1359432X.2013.763403

Gubler M, Bienann T, Tshopp C, Grote G (2015) How career anchors differentiate managerial career trajectories: a sequence analysis perspective. Journal of Career Development 42 (5): 412-430. https://doi.org/10.1177/0894845315572891

Hair J, Black W, Babin B, Anderson R (2014) Multivariate data analysis. London: Pearson Education Limited.

Hall D, Mirvis P (1995) The new protean career contract: helping organizations and employees adapt. Journal of Vocational Behavior 74: 269289. https://doi.org/10.1006/jvbe.1995.0004

Igbaria M, Greenhaus J, Parasuraman S (1991) Career orientations of MIS employees: an empirical analysis. MIS Quarterly 15 (2): $151-169$. https://doi.org/10.2307/249376

International Labour Organization (ILO) (2016) Labour overview of Latin America and the Caribbean. ILO, Lima.

Ituma A, Simpson R (2007) Moving beyond Schein's typology: individual career anchors in the context of Nigeria. Personnel Review 36 (6): 978-995. https://doi.org/10.1108/00483480710822463

Kaiser H (1970) A second generation little jiffy. Psychometrika 35 (4): 401-415. https://doi.org/10.1007/BF02291817

Kaplan D (2014) Career anchors and paths: the case of gay, lesbian, \& bisexual workers. Human Resource Management Review 24 (2): 119 130. https://doi.org/10.1016/j.hrmr.2013.10.002

Kaplan R, Shmulevitz C, Raviv D (2009) Reaching the top: career anchors and professional development in nursing. International Journal of Nursing Education Scholarship 6 (1): article number 24. https://doi.org/10.2202/1548-923X.1482

La-Lopa J, Beck J, Ghiselli R (2009) The role of biodata and career anchors on turnover intentions among hospitality and tourism educators. Journal of Culinary Science and Technology 7 (2-3): 196-206. https://doi.org/10.1080/15428050903397112

Leong F, Rosenberg S, Chong S (2014) A psychometric evaluation of Schein's (1985) Career Orientations Inventory. Journal of Career Assessment 22 (3): 524-538. https://doi.org/10.1177/1069072713498685

López H (2009) El Mercado laboral colombiano: tendencias de largo plazo y sugerencias de política. Banco de la Republica. Bogota. 
Luo O, Zhang O (2011) Research on physical education students' career anchors types in Hubei province. Journal of Convergence Information Technology 6 (8): 382-386. https://doi.org/10.4156/jcit.vol6.issue8.46

Marshall V, Bonner D (2003) Career anchors and the effects of downsizing: implications for generations and cultures at work. A preliminary investigation. Journal of European Industrial Training 27 (6): 281-291. https://doi.org/10.1108/03090590310479910

McDonald P, Brown K, Bradley L (2005) Have traditional career paths given way to protean ones? Evidence from senior managers in the Australian public sector. Career Development International 10 (2): 109-129. https://doi.org/10.1108/13620430510588310

Mihail D (2008) Graduates' career orientations and strategies in corporate Greece. Personnel Review 37 (4): $393-411$. https://doi.org/10.1108/00483480810877570

Miranda Z, Vieira L, De-Souza A, Rodrigues D (2011) Career paths, images and anchors: a study with Brazilian professionals. The Qualitative Report 16 (1): 147-161.

Nordvik H (1996) Relationships between Holland's vocational typology, Schein's career anchors and Myers-Briggs' types. Journal of Occupational and Organizational Psychology 69: 263-275. https://doi.org/10.1111/j.2044-8325.1996.tb00614.x

Open Science Collaboration (2015) Estimating the reproducibility of psychological science. Science 349 (6251): 943.

Rodrigues R, Guest D, Budjanovcanin A (2013) From anchors to orientations: towards a contemporary theory of career preferences. Journal of Vocational Behavior 82 (2): 142-152. https://doi.org/10.1016/j.jvb.2013.04.002

Roger A (2006) Développement et validation d'une échelle de mesure des orientations de carrière individuelles. In: $14 \mathrm{e}$ Congrès de l'Association internationale de psychologie du travail de langue française (AIPTLF), Tunisia, AIPTLF.

Schein E (1974) Career anchors and career paths: a panel study of management school graduates. Massachusetts: MIT - Sloan School of Management, Cambridge.

Schein E (1975) How career anchors hold executives to their career patch. Personnel 52 (3): 11-24.

Schein E (1978) Career dynamics: matching individual and organizational needs. New Jersey: Prentice-Hall.

Schein E (1987) Individuals and careers. In Lorsch JW (Ed) Handbook of Organizational Behavior. New Jersey: Prentice-Hall, $155-171$.

Schein E (1990) Career anchor and job/role planning: the links between career pathing and career development. Massachusetts: MIT-Sloan School of Management, Cambridge.

Schwartz S, Boehnke, K (2004) Evaluating the structure of human values with confirmatory factor analysis. Journal of Research in Personality 38 (3): 230-255.

Tremblay M, Dahan J, Gianecchine M (2014) The mediating influence of career success in relationship between career mobility criteria, career anchors, and satisfaction with organization. Personnel Review 43 (6): 818-844.

Wils L, Wils T, Tremblay M (2010) Toward a career anchor structure: an empirical investigation of engineers. Relations Industrielles/Industrial Relations 65 (2): 236-256.

Wils, T, Wils L, Tremblay, M (2014) Revisiting the career anchor model: a proposition and an empirical investigation of a new model of career value structure. Relations Industrieles / Industrial Relations 69 (4): 813-838.

\section{Appendix}

Questionnaire: anchors, definition, and items on the questionnaire.

\begin{tabular}{|c|c|c|}
\hline Anchor & Definition & Items on the questionnaire \\
\hline \multirow{5}{*}{ Functional/technical competence } & \multirow{5}{*}{$\begin{array}{l}\text { Primarily excited by the content of } \\
\text { the work itself; prefers advancement } \\
\text { only in his/her technical or } \\
\text { functional area of competence; } \\
\text { generally disdains and fears general } \\
\text { management as too political. }\end{array}$} & $\begin{array}{l}\text { I dream of being so good at what I do that my expert } \\
\text { advice will be sought continuously. }\end{array}$ \\
\hline & & $\begin{array}{l}\text { I will feel successful in my career only if I can } \\
\text { develop my technical or functional skills to a very } \\
\text { high level of competence. }\end{array}$ \\
\hline & & $\begin{array}{l}\text { Becoming a senior functional manager in my area of } \\
\text { expertise is more attractive to me than becoming a } \\
\text { general manager. }\end{array}$ \\
\hline & & $\begin{array}{l}\text { I would rather leave my organization than accept a } \\
\text { rotational assignment that would take me out of my } \\
\text { area of expertise. }\end{array}$ \\
\hline & & $\begin{array}{l}\text { I am most fulfilled in my work when I am able to use } \\
\text { my special skills and talents. }\end{array}$ \\
\hline \multirow{5}{*}{ Managerial competence } & \multirow{5}{*}{$\begin{array}{l}\text { Primarily excited by the opportunity } \\
\text { to analyze and solve problems under } \\
\text { conditions of incomplete } \\
\text { information and uncertainty; likes } \\
\text { harnessing the efforts of people to } \\
\text { achieve common goals; stimulated } \\
\text { (rather than exhausted) by crisis } \\
\text { situations. }\end{array}$} & $\begin{array}{l}\text { I am most fulfilled in my work when I have been able } \\
\text { to integrate and manage the efforts of others. }\end{array}$ \\
\hline & & $\begin{array}{l}\text { I dream of being in charge of a complex organization } \\
\text { and making decisions that affect many people. }\end{array}$ \\
\hline & & $\begin{array}{l}\text { I will feel successful in my career only if I become a } \\
\text { general manager in some organization. }\end{array}$ \\
\hline & & $\begin{array}{l}\text { Becoming a general manager is more attractive to me } \\
\text { than becoming a senior functional manager in my } \\
\text { current area of expertise. }\end{array}$ \\
\hline & & $\begin{array}{l}\text { I would rather leave my organization than accept a } \\
\text { job that would take me away from the general } \\
\text { managerial track. }\end{array}$ \\
\hline
\end{tabular}


Primarily motivated to seek work situations that are maximally free of organizational constraints; wants to set own schedule and own pace of work; is willing to trade-off opportunities for promotion to have more freedom.

Primarily motivated by job security and long-term attachment to one organization; willing to conform and to be fully socialized into an organization's values and norms; tends to dislike travel and relocation.

Primarily motivated by the need to build or create something that is entirely his/her own project; easily bored and likes to move from project to project; more interested in initiating new enterprises than managing established ones.

Primarily motivated to improve the world in some fashion; wants to

Service/dedication

Pure challenge values about helping society; more concerned with finding jobs that meet his/her values than skills.
I dream of having a career that will allow me the freedom to do a job my own way and according to my own schedule.

I am most fulfilled in my work when I am completely free to define my own tasks, schedules, and procedures.

I will feel successful in my career only if I achieve complete autonomy and freedom.

The chance to do a job my own way, free of rules and constraints, is more important to me than security.

I would rather leave my organization than accept a job that would reduce my autonomy and freedom.

Security and stability are more important to me than freedom and autonomy.

I am most fulfilled in my work when I am completely free to define my own tasks, schedules, and procedures.

I seek jobs in organizations that will give me a sense of security and stability.

I am most fulfilled in my work when I feel that I have complete financial and employment security.

I dream of having a career that will allow me to feel a sense of security and stability.

I am always on the lookout for ideas that would permit me to start my own enterprise.

Building my own business is more important to me than achieving a high-level managerial position in someone else's organization.

I dream of starting up and building my own business.

I am most fulfilled in my career when I have been

able to build something that is entirely the result of my own ideas and efforts.

I will feel successful in my career only if I have succeeded in creating or building something that is entirely my own product or idea.

I will feel successful in my career only if I have a feeling of having made a real contribution to the welfare of society.

I am most fulfilled in my career when I have been able to use my talents in the service of others.

Using my skills to make the world a better place to live and work in is more important to me than achieving a high-level managerial position.

I dream of having a career that makes a real contribution to humanity and society.

I would rather leave my organization than accept an assignment that would undermine my ability to be of service to others.

I dream of a career in which I can solve problems or win out in situations that are extremely challenging.

I will feel successful in my career only if I face and overcome very difficult challenges.

I have been most fulfilled in my career when I have solved seemingly unsolvable problems or won out over seemingly impossible odds.

I seek out work opportunities that strongly challenge my problem-solving and/or competitive skills.

Working on problems that are almost unsolvable is more important to me than achieving a high-level managerial position.

I would rather leave my organization than be placed in a job that would compromise my ability to pursue personal and family concerns. 


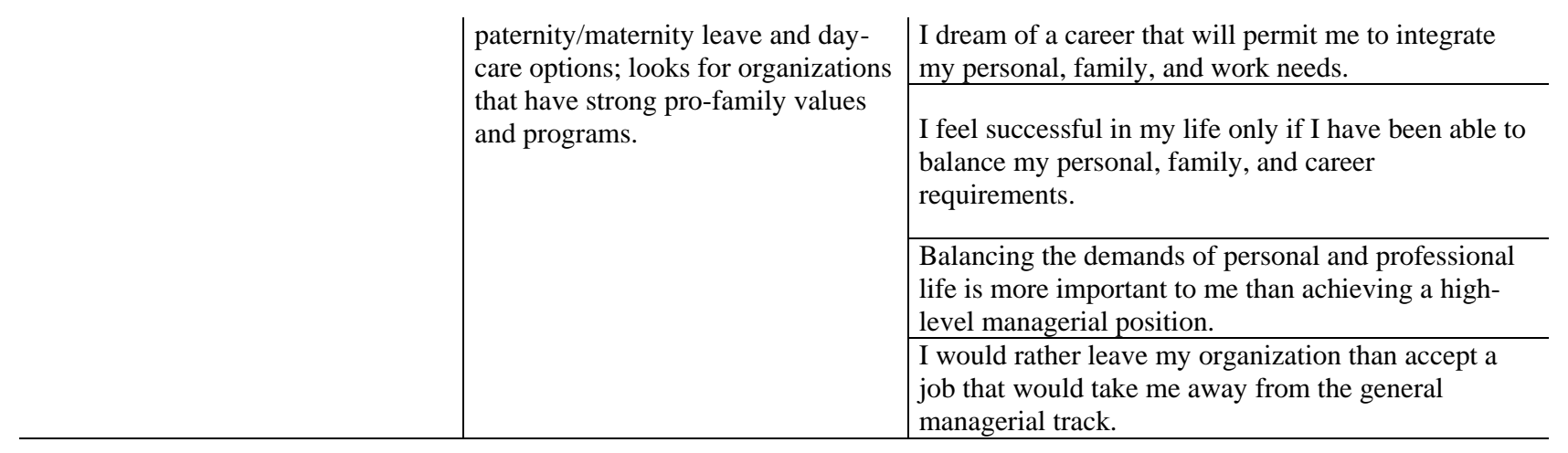

(source: Danziger et al. 2008: 9-10). The table has been edited.

Julián David CORTÉS-SÁNCHEZ. Assistant Professor at Universidad del Rosario - School of Management (Colombia). Holds a M.Sc. in interdisciplinary development studies from Universidad de los Andes (Colombia).

Merlin Patricia GRUESO-HINESTROZA. Full Professor at Universidad del Rosario - School of Management (Colombia). Holds a PhD in Social Psychology and Organizational Anthropology from Universidad de Salamanca (Spain). 